\title{
ОБЛІК, АУДИТ ТА УПРАВЛІННЯ КРЕДИТОРСЬКОЮ ЗАБОРГОВАНІСТЮ
}

\section{ACCOUNTING, AUDIT AND MANAGEMENT OF PAYABLES}

\author{
Бондаренко Ольга Михайлівна \\ кандидат економічних наук, доцент, \\ Національний авіаційний університет \\ ORCID: https://orcid.org/0000-0002-6546-7336 \\ Матвєева Ольга Миколаївна \\ кандидат економічних наук, доцент, \\ Національний авіаційний університет \\ ORCID: https://orcid.org/0000-0002-7648-6065 \\ Ковальова Валерія юріївна \\ студентка, \\ Національний авіаційний університет \\ ORCID: https://orcid.org/0000-0002-4195-8368
}

\author{
Bondarenko Olga, Matveeva Olga, Kovalyova Valeriia \\ National Aviation University
}

\begin{abstract}
У даній статті досліджено теоретичні та практичні питання щодо визначення сутності кредиторської заборгованості, її руху в господарській діяльності; розглянуто основні методи проведення аудиту кредиторської заборгованості згідно до Міжнародних стандартів; особливості ефективного управління поточними зобов'язаннями підприємства; аналіз поточної кредиторської заборгованості; облік кредиторської заборгованості. Визначено місце поточних зобов'язань у діяльності підприємства. Повна та достовірна інсрормація забезпечує прийняття управлінських рішень щодо кредиторської заборгованості на підприємстві. Особливе місце в кредиторський заборгованості займають численні розрахунки з постачальниками і підрядниками. Ефективне управління кредиторською заборгованістю належить до необхідних умов успішної діяльності, оскільки воно створює передумови для швидкого розвитку бізнесу і збільшення фрінансових можливостей підприємства.
\end{abstract}

Ключові слова: кредиторська заборгованість, аудит, міжнародні стандарти, аудитор, облік, аналіз, зобов'язання, управління.

В данной статье исследованы теоретические и практические вопросы по определению сущности кредиторской задолженности, ее движения в хозяйственной деятельности; рассмотрены основные методы проведения аудита кредиторской задолженности согласно Международным стандартам; особенности эфффективного управления текущими обязательствами предприятия; анализ текущей кредиторской задолженности; бухгалтерский учет кредиторской задолженности. Определено место текущих обязательств в деятельности предприятия. Полная и достоверная информация обеспечивает принятие управленческих решений по кредиторской задолженности на предприятии. Особое место в кредиторской задолженности занимают многочисленные расчеты с поставщиками и подрядчиками. Эфрфективное управление кредиторской задолженностью относится к необходимым условиям успешной деятельности, поскольку оно создает предпосылки для быстрого развития бизнеса и увеличения фринансовых возможностей предприятия.

Ключевые слова: кредиторская задолженность, аудит, международные стандарты, аудитор, учет, анализ, обязательства, управление.

This article examines the theoretical and practical issues of determining the nature of accounts payable, its movement in economic activity; the main methods of auditing accounts payable in accordance with International Standards are considered; features of effective management of current liabilities of the enterprise; analysis of current accounts payable; accounts payable. The place of current liabilities in the activity of the enterprise is determined. Complete and reliable information ensures the adoption of management decisions on accounts payable at the en- 
terprise. A special place in accounts payable is occupied by numerous settlements with suppliers and contractors. Components of accounts payable are considered. Accounts payable are defined as «obligations to pay goods or services that have been received or delivered or that have been invoices were issued, or they were formally agreed with supplier». Accounts payable provide an opportunity the company temporarily use the borrowed funds but with on the other hand - reduces the solvency and liquidity.Effective management of accounts payable is a necessary condition for successful operation as it creates the conditions for rapid business development and increase the financial capabilities of the enterprise. These articles also consider the theoretical provisions and the development of methodological approaches and practical recommendations aimed at improving the audit of liabilities of enterprises. Analysis and research of scientific and practical literature, as well as standards governing the audit of financial statements allowed to justify the peculiarities of the methodology of auditing the liabilities of enterprises. Some components of the methodological support and methods of auditing the liabilities of the enterprise are highlighted. The stages of the audit are summarized and identifies audit procedures that are substantive of the audit plan for the entity's liabilities. The achievements concerning the peculiarities of the formation of the methodology of audit of the company's liabilities at the present stage of development of auditing activities in Ukraine in particular approaches to determining the procedure for auditing long-term liabilities of the enterprise and short-term liabilities enterprises. The algorithm of the methodology of audit of current liabilities of the enterprise is presented separately.

Keywords: accounts payable, audit, international standards, auditor, accounting, analysis, commitment, management.

Постановка проблеми. Облік взаєморозрахунків із кредиторами - це обов'язкова необхідність роботи будь-якого підприємства. Правильне та достовірне відображення в бухгалтерському обліку і звітності поточних зобов'язань має надзвичайне значення, оскільки така заборгованість впливає на платоспроможність підприємства [1]. У процесі своєї діяльності підприємства співпрацюють із різними юридичними або фрізичними особами та державними органами, тому в результаті їх взаємовідносин виникають зобов'язання. Зобов'язання $€$ важливим аспектом, який впливає на фрінансову стійкість підприємства взагалі, тому дане питання щодо визначення сутності та змісту останніх $€$ актуальним і важливим, адже від ефективності управління зобов'язаннями в цілому залежать перспективи розвитку підприємства у майбутньому. Проведення аудиту зобов'язань підприємств має на меті виявлення достовірної інорормації відносно наявності зобов'язань у підприємства перед контрагентами (кредиторами), повноти та своєчасності відображання первинних даних в облікових і звітних документах, правильності ведення обліку зобов'язань, а також його відповідності прийнятій обліковій політиці, реальності існуючих зобов'язань, законності та доцільності проведених розрахунків, достовірності відображання стану зобов'язань у звітності підприємств.

Аналіз останніх досліджень і публікацій. Дослідженням та удосконаленням проблемних питань аудиту кредиторської заборгованості присвячено роботи наступних зарубіжних вчених, як: Р. Адамс, Ф. Л. Десрліз, Г. Р. Дженік, А. Аренс, Дж. Лоббек, М. Готліб, Р. Додж, К. Друрі, Д. Робертсон, В. Д. Андреєв,
С. М. Бичкова, Н. М. Заваріхіна, С. В. Панкова, В. І. Подольський, В. П. Суйц, саме вони найбільше приділяють увагу методиці проведення аудиту на основі Міжнародних стандартів аудиту. Вітчизняна практика базується на розробках та дослідженнях таких українських вчених: М. Т. Білухи, Ф. Ф. Бутинця, Г.М.Давидова, Н. І. Дорош, О. А. Петрик, О. Ю. Редька, В. С. Рудницького, В. О. Шевчука, Б. Ф. Усача, Н. М. Проскуріної й ін.

Мета дослідження. Огляд методики та проблемних питань аудиторської перевірки та управління поточною кредиторською заборгованості на підприємствах.

Виклад основного матеріалу. Основними завданнями обліку кредиторської заборгованості є: достовірне і повне забезпечення інфрормацією щодо стану розрахунків 3 кредиторами; забезпечення своєчасного контролю за виконанням зобов'язань. Однією з проблем під час роботи кожного підприємства $€$ здатність максимально швидкого погашення своєї кредиторської заборгованості. Саме для цього необхідно постійно контролювати збалансований обсяг кредиторської заборгованості, підтримувати оборотність заборгованості та відстежувати ії структуру (склад).

Проведення аналізу можливе лише за умови правдивої інформації з системи бухгалтерського обліку підприємства, а саме: бухгалтерського балансу, звіту про фрінансові результату, приміток до річної фрінансової звітності, регістрів бухгалтерського обліку та ін.

Зазначимо, що на підставі бухгалтерської інсрормації можна розрахувати оптимальну структуру зобов'язань суб'єкта господарювання, скласти бюджет своїх зобов'язань, 
виявити та проаналізувати низку показників, які нададуть кількісну і якісну оцінку роботи між контрагентами.

Лише після проведення аналізу своїх поточних зобов'язань можна з'ясувати причини їх виникнення та запропонувати механізм управління поточною кредиторською заборгованістю.

Крім проведення аналізу поточної кредиторської заборгованості, пропонуємо також провести на підприємстві незалежний аудит, який надасть можливість виявити факти некоректного ведення обліку поточних зобов'язань та розкриє відхилення в структурі та складі зобов'язань.

Незалежна аудиторська перевірка сприяє забезпеченню достовірності його фрінансової звітності. Одним із важливих напрямків перевірки практично для всіх господарюючих суб'єктів є аудит поточних зобов'язань, який направлений на оцінку системи обліку і встановлення зловживань та помилок.

Не існує стандарту, який регулює аудит поточних зобов'язань, але затверджено наступні Міжнародні стандарти аудиту, що регламентують різноманітні етапи аудиторської перевірки: МСА 230 «Аудиторська документація», МСА 500 «Поняття й види аудиторських доказів», МСА 505 «Зовнішні підтвердження», MCA 530 «Аудиторська вибірка» тощо [2].

Аудит поточних зобов'язань базується на перевірці дотримання методологічних засад фрормування в обліку інфрормації про поточну заборгованість підприємства перед кредиторами (постачальниками та підрядниками, можливе виявлення заборгованості перед покупцями), а також достовірність розкриття інфрормації про них у фрінансовій звітності.

Основними завданнями аудиту розрахунків 3 постачальниками та підрядниками $є$ : перевірка оформлення первинних документів; їх наявність; підстави виникнення кредиторської заборгованості; своєчасність її погашення; правильність відображення в обліку; дотримання фрінансово-розрахункової дисципліни; перевірка достовірності інорормації у регістрах бухгалтерського обліку та фрінансовій звітності.

Якість проведення аудиту залежить від вибраних аудиторських процедур та методів. Їх вибір - це результат профресійності аудитора, його кваліфікації та досвіду. Процедури складаються 3 певної послідовності застосовуваних методів. Необхідно підібрати оптимальну кількість методичних прийомів для отримання достатніх аудиторських доказів, що дадуть можливість сорормулювати обґрунтовані висновки які необхідні для проведення аудиту розрахунків із кредиторами. Планування аудиторських процедур повинно здійснюватися відповідно до норм МСА 500 «Аудиторські докази» [2].

Дослідження документів та відображення інорормації в облікових регістрах - одна 3 найважливіших процедур аудиту. У ході перевірки розрахунків з постачальниками та підрядниками аудитор перевіряє первинні документи: прибуткові, податкові накладні, банківські виписки. Аудитор має встановити правильність кореспонденції рахунків бухгалтерського обліку, виявити не тільки помилки, а й розкрити факти навмисного викривлення облікових даних з метою приховування допущених зловживань.

Важливим $€$ супроводження проведення інвентаризації. Аналіз її проведення $€$ реалізацією аудиторської процедури «спостереження».

В ході аудиторської перевірки застосовується процедура запиту. Для отримання зовнішніх підтверджень аудитору потрібно надіслати запит до підприємства для підтвердження заборгованості. 3 загального переліку контрагентів відбираються, виходячи із рівня суттєвості та запланованих аудиторських ризиків ті контрагенти, яким направляються запити. Оцінивши отримані відповіді, аудитор фрормує свою думку від відібраних контрагентів та приймає рішення відносно застосування або незастосування інших аудиторських процедур.

Оскільки виникнення кредиторської заборгованості за товари, роботи, послуги характеризується великою кількістю зовнішніх контрагентів, то для її аудиторської перевірки доцільно застосувати аудиторську вибірку. Проведення аудиторської вибірки передбачає дослідження бухгалтерських записів шляхом відбору певної кількості необхідних даних, які дадуть змогу достовірно оцінити всю сукупність, яка не охоплена дослідженням.

Провівши аудиторські процедури для одержання аудиторських доказів, аудитор робить висновок щодо наявної кредиторської заборгованості за товари, роботи, послуги, підтверджує правильність оформлених первинних документів, їх законність. Аудиторський висновок містить інформацію про достовірність відображення заборгованості на рахунках бухгалтерського обліку та у фрінансовій звітності.

Вважаємо, що отримання інформації з незалежного аудиту надасть можливість прийняти 
рішення щодо відстрочки погашення своїх зобов'язань та попередження виникнення простроченої кредиторської заборгованістю, у якої підходить строк позовної давності.

Тобто, лише на підставі всієї об'єктивної та неупередженої інсрормації з різних джерел ії надходження можна запропонувати обґрунтовані ефективні управлінські рішення з подальшого контролю, планування та управління поточною кредиторською заборгованістю.

При правильному вибору механізму управління своїми зобов'язаннями поточна кредиторська заборгованість $€$ додатковою можливістю залучення активів на підприємство.

Одним із напрямків управління заборгованістю $€$ виявлення джерел перерахунку своїх зобов'язань та розрахунок ефективності використання в обороті залучених та позикових коштів.
Іншими словами, ефективність механізму управління кредиторською заборгованістю полягає у правильності прийняття рішення щодо вибору форми зобов'язання 3 метою мінімізації відсоткових виплат та встановленням оптимальної форми кредитування.

На нашу думку, ефективне управління поточними зобов'язаннями надає можливість підприємству застосувати найбільше вигідні фрорми і терміни розрахунків та зводиться для збереження фрінансової стабільності підприємства.

Пустяк О.В. та Демченко Я.М. пропонують під час управління кредиторською заборгованістю застосовувати наступний алгоритм її управлінням (рис. 1) [3].

Важливим завданням управління зобов'язаннями $є$ заходи, які спрямовані на оптимізацію кредиторської заборгованості. Пропонуємо для удосконалення механізму

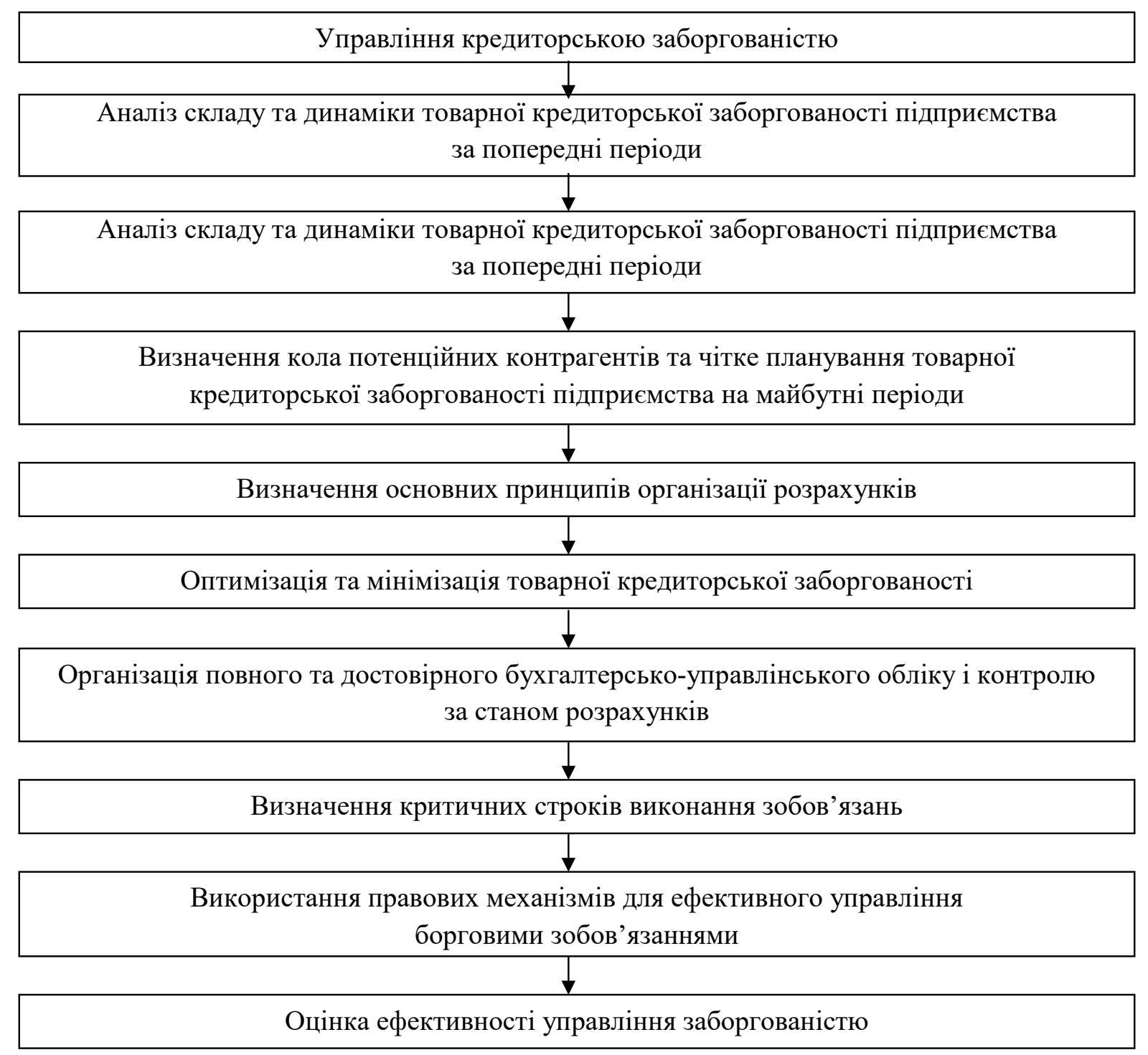

Рис. 1. Алгоритм управління кредиторською заборгованістю [3] 


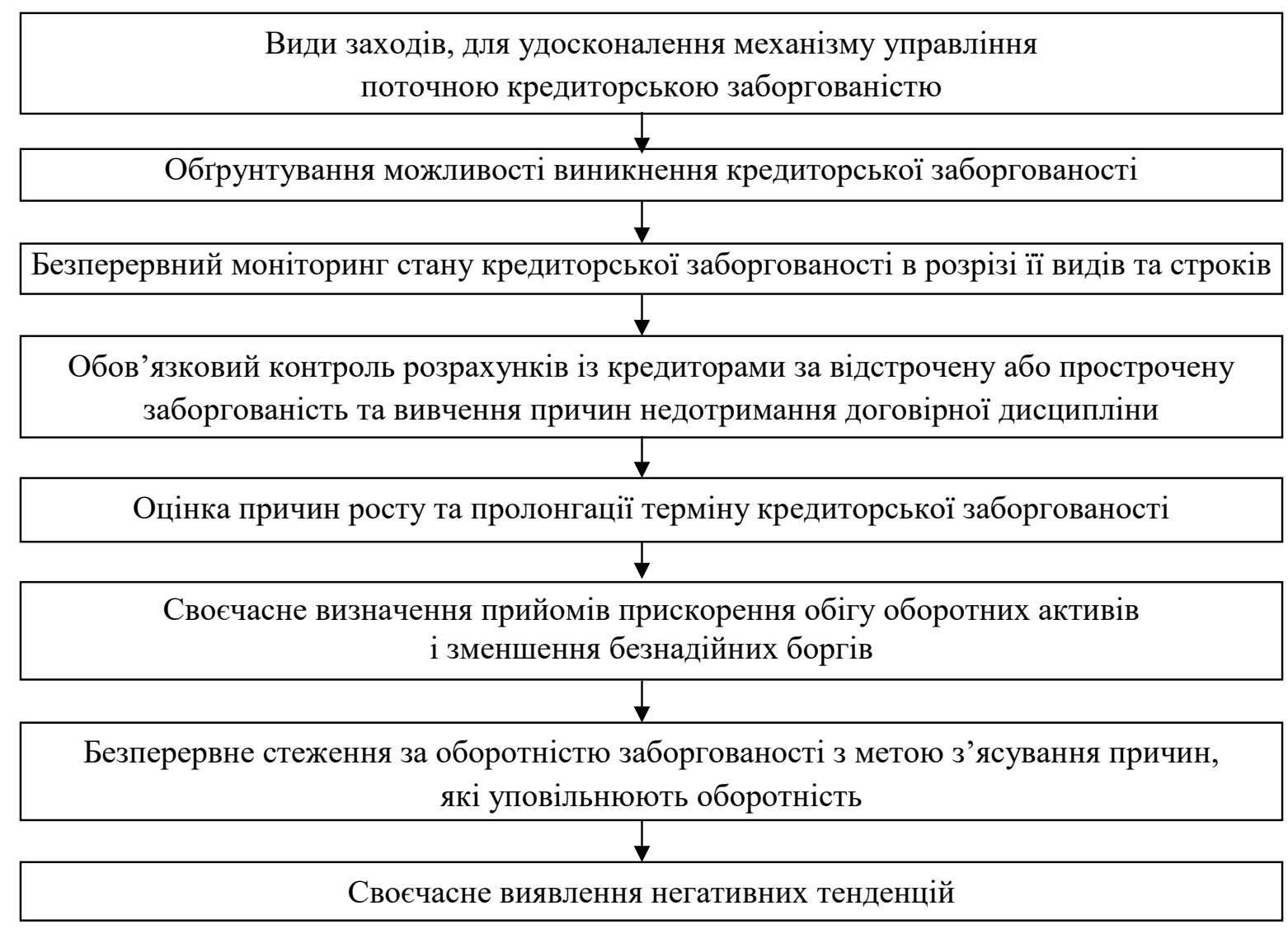

Рис. 2. Види заходів, для удосконалення механізму управління поточною кредиторською заборгованістю

Джерело: систематизовано авторами

управління поточною кредиторською заборгованістю застосувати заходи наведені на рисунку 2. Вважаємо, що під час дотримування цих заходів, а також проведення постійного моніторингу обліку та контролю стану поточних зобов'язань призведе до ефективного механізму управління поточною кредиторською заборгованістю.

Таким чином, управління поточною кредиторською заборгованістю підприємства $€$ одним із важливих напрямків роботи підприємства, результат якого повинен привести до стабілізації фрінансового стану підприємства.

Висновки. Ефективне управління кредиторською заборгованістю підприємства залежить від можливості отримати якісну інфрормацію про стан та динаміку розміру кредиторської заборгованості, виявлення резервів її оптимізації.

Саме тому, проведення аудиту кредиторської заборгованості має велику актуальність, так як стимулює підприємство регулярно проводити аналіз та інвентаризацію кредиторської заборгованості, вживати заходів щодо стягнення заборгованості з неплатників.

Якісне проведення аудиторської перевірки гарантує користувачам фрінансової звітності отримання достовірної, реальної, повної та легітивної інфрормації про кредиторську заборгованість. Від висновків аудитора та прийнятих рішень управлінського персоналу залежить стан та перспективи розвитку підприємства в майбутньому.

\section{СПИСОК ВИКОРИСТАНИХ ДЖЕРЕЛ:}

1. Левчинський Д.Л., Морозова Є.П. Основні засади аудиту кредиторської заборгованості згідно з міжнародними стандартами. Інтелект. 2016. Випуск 5. URL: http://www.intellect21.nuft.org.ua/journal/2016/2016_5/2.pdf

2. Міжнародні стандарти контролю якості, аудиту, огляду, іншого надання впевненості та супутніх послуг. Частина 1, 2016-2017рp. URL: https://mof.gov.ua/storage/files/2016-2017-IAASB-Handbook-Volume1_\%D1\%83\%D0\%BA\%D1\%80.pdf (дата звернення: 22.03.2021). 
3. Пустяк О.В., Демченко Я.М. Ефективність управління кредиторською заборгованістю за товари, роботи, послуги: обліково-аналітичний аспект. Економіка і регіон. 2105. № 3(52). С. 88-95.

\section{REFERENCES:}

1. Levchinsky D.L., Morozova E.P. (2016). Basic principles of audit of accounts payable in accordance with international standards. Intelligence, issue 5. URL: http://www.intellect21.nuft.org.ua/journal/2016/2016_5/2.pdf

2. International standards for quality control, audit, inspection, other assurance and related services. Part 1, 2016-2017. URL: https://mof.gov.ua/storage/files/2016-2017-IAASB-Handbook-Volume-1_\%D1\%83\%D0\% BA\%D1\%80.pdf (accessed 22 March 2021).

3. Pustyak O.V., Demchenko Ya.M. (2015). Effectiveness of accounts payable management for goods, works, services: accounting and analytical aspect. Economy and region, no. 3(52), pp. 88-95. 